\title{
Morphological characterization and genetic analysis of Drechslera teres isolates
}

\author{
A.P.G. Frazzon ${ }^{1}$, A.T.S. Matsumura ${ }^{1}$ and S.T. Van Der Sand ${ }^{2}$ \\ ${ }^{1}$ Depto. de Fitossanidade, Universidade Federal do Rio Grande do Sul, Porto Alegre, RS, Brazil. \\ ${ }^{2}$ Departamento de Microbiologia, Instituto de Ciências Básicas da Saúde, UFRGS, Porto Alegre, \\ RS, Brazil.
}

\begin{abstract}
Net blotch, caused by the phytopathogen Drechslera teres, is a common disease of barley (Hordeum vulgare $L$ ) and is responsible for large economic losses in some barley growing areas. In this study the morphology and genetic variability of eight $D$. teres isolates from different regions of the Brazilian state of Rio Grande do Sul were investigated. Colony morphology was studied on potato-dextrose-agar (PDA) and genetic variability investigated using the random amplified polymorphic-DNA (RAPD) technique. 27 commercially available primers were tested of which 16 were selected for use in polymorphic analysis due to their good resolution and reproducibility. Similarity coefficients were used to construct dendrograms based on colony morphology and RAPD data showing the relationship between the eight isolates studied. Colony morphology showed variability between the isolates while RAPD assays showed high similarity coefficients, but grouping of the isolates according to the geographic origins of the seeds from which they were isolated was not possible.
\end{abstract}

Key words: Drechslera teres, barley, net blotch, DNA polymorphism, RAPD.

Received: May 18, 1999; accepted: February 5, 2001.

\section{Introduction}

Barley (Hordeum vulgare L) is an intensively cultivated cereal grown worldwide, being cultivated in Brazil mainly in the southern state of Rio Grande do Sul (Leal, 1972). The most important disease of barley is net blot, caused by the phytopathogenic fungus Drechslera teres (Sacc) Schoemaker; teleomorphic stage: Pyrenophora teres Drechs., (syn. Helminthosporium teres Sacc.) (Alexopoulus and Mims, 1985; Mather, 1987). Both the seeds and leaves of barley can be infected by $D$. teres, which can also persist in straw (Mather, 1987). Heterokaryosis, sexual recombination and parasexuality all contribut to the enormous variability and diversity of this fungus (Azevedo, 1976).

Random amplified polymorphic DNA (RAPD, Williams et al. 1990), has often been used in characterization studies of phytopathogenic fungi, for example in the study of Fusarium oxysporum races and formae speciales (Jesus et al., 1995) and to investigate variations between isolates of Rhizoctonia solani (Duncan, et al., 1993), Puccinia striiforms (Chen, et al., 1993) and other fungi.

Send correspondence to S.T. Van Der Sand. E-mail: svands@ @ortex.ufrgs.br.
The aim of the work reported in this paper was to investigate morphological aspects of different $D$. teres isolates using traditional microbiological methods and chromosomal DNA polymorphisms using RAPD analysis.

\section{Material and Methods}

\section{Isolation of fungi}

Seeds of Barley (Hordeum vulgare L) cultivar MN599 were obtained from a malting-house (Maltaria Navegantes) in Porto Alegre, Rio Grande do Sul, Brazil. The geographic origin of the seeds from which the $D$. teres were isolated are given in Table I. The fungi were isolated from the seeds by sanitizing the seeds by immersion in $2 \%$ aqueous sodium hypochlorite for $120 \mathrm{~s}$, washing them 3 times in sterile water and incubating them on wet filter paper in a tray for 10 days at $24{ }^{\circ} \mathrm{C}$ with a $12 \mathrm{~h}$ photoperiod. Conidia of $D$. teres were collected from each seed and inoculated onto plates of potato-dextrose-agar (PDA) which were also incubated for 7 days at $24{ }^{\circ} \mathrm{C}$ with a $12 \mathrm{~h}$ photoperiod. After confirmation of the vegetative structure of the fungi, conidia were transferred to PDA slants and 
Table I - Isolation of Drechslera teres from barley seeds.

\begin{tabular}{lc}
\hline Geographic origin of the host seeds & D. teres code \\
\hline Sananduva $^{\mathrm{a}}$ (high plateau region) & Sanad599 \\
Ipiranga do Sul (middle plateau region) $^{\mathrm{b}}$ & Ipira599 \\
Palmeira das Missões (middle plateau region) & Palme599 \\
São Gabriel (prairie region) & Saog599 \\
Encruzilhada do Sul (southeastern mountains region) & Encru599 \\
Vacaria (high plateau region) & Vacar599 \\
Piratini (southeastern mountains region) & Pirat599 \\
Carazinho (middle plateau region) & Caraz599 \\
\hline
\end{tabular}

${ }^{a}$ Nearest town to where the seeds were collected.

${ }^{\mathrm{b}}$ Geographic region of Rio Grande do Sul state, Brazil.

incubated as before. All strains were stored as conidia and hyphae at $4{ }^{\circ} \mathrm{C}$.

\section{Morphological analysis}

For each $D$. teres isolate a $0.5 \mathrm{~cm}$ diameter paper disk containing isolated conidia was placed at the center of a PDA plate, five replicates being made for each strain. Using the key produced by Nobles (1958), the macroscopic characters (color, sector, border and texture) of each colony were recorded at 24-hour interval until one of the colonies had reached the border of the plate.

\section{DNA extraction}

Genomic DNA was extracted from mycelium using a modified Ashktorab and Cohen (1992) method. Isolates of $D$. teres were grown in $100 \mathrm{~mL}$ of potato-dextrose broth (20\% potato, $2 \%$ dextrose $(\mathrm{w} / \mathrm{v}))$ for 10 days at $24 \pm 2{ }^{\circ} \mathrm{C}$ with $12 \mathrm{~h}$ photoperiod. After which $20 \mathrm{~g}$ of wet mycelia were separated by filtration, washed three times with sterile water, transferred to a mortar and ground to a fine powder in liquid nitrogen. To this powder was added $20 \mathrm{~mL}$ of extraction buffer (200 mM Tris- $\mathrm{HCl} \mathrm{pH} 8.0 ; 250 \mathrm{mM} \mathrm{NaCl}$; $25 \mathrm{mM}$ EDTA pH 8.0; $50 \mu \mathrm{g} / \mathrm{mL}$ proteinase $\mathrm{K} ; 1 \%$ (v/v) of sodium dodecyl sulfate and $1 \%(\mathrm{v} / \mathrm{v}) \beta$-mercaptanol). The suspension was incubated for $1 \mathrm{~h}$ at $65^{\circ} \mathrm{C}$. The suspension was then centrifuged at $4.000 \mathrm{rpm}$ for $20 \mathrm{~min}$ and the supernatant extracted once with phenol, twice with phenol-chloroform and once with chloroform. The DNA was precipitated with $100 \%$ ethanol and $3 \mathrm{M} \mathrm{NaCl}$, washed with $70 \%$ ethanol, dried, re-suspended in TE buffer $(10 \mathrm{mM}$ Tris-HCl, $\mathrm{pH} 8.0 ; 1 \mathrm{mM}$ EDTA ) and stored at $-20{ }^{\circ} \mathrm{C}$.

\section{Primers and amplification conditions}

The primers (Table II) were obtained from Byodinamics SRL (Buenos Aires, Argentina) and OPERON Technology (Alameda, CA). The RAPD reactions were performed in $25 \mu \mathrm{L}$ volumes containing $10 \mathrm{mM}$ Tris $\mathrm{HCl}$

Table II - Sequences of the 16 primers used in this study and size in kilobases $(\mathrm{kb})$ of the amplified Drechslera teres DNA fragment.

\begin{tabular}{|c|c|c|c|}
\hline Primer & Sequence $5^{\prime}-3^{\prime}$ & Fragment size $(\mathrm{kb})$ & D. teres isolate \\
\hline A01 & CCCAAGGTCC & $\begin{array}{l}1.69 \\
0.97 \\
0.74 \\
0.67 \\
0.61\end{array}$ & $\begin{array}{l}\text { Vacar599 } \\
\text { Vacar599 } \\
\text { Sanad599, Saog599, Encru599 } \\
\text { All isolates } \\
\text { All isolates }\end{array}$ \\
\hline $\mathrm{A} 02$ & GGTGCGGGAA & $\begin{array}{l}1.68 \\
1.39 \\
1.02\end{array}$ & $\begin{array}{l}\text { All isolates } \\
\text { Ipira599 } \\
\text { All isolates }\end{array}$ \\
\hline A06 & GAGTCTCAGG & $\begin{array}{l}1.77 \\
1.23 \\
0.96 \\
0.81 \\
0.73\end{array}$ & $\begin{array}{l}\text { All isolates } \\
\text { Ipira599 } \\
\text { All isolates } \\
\text { Saog599, Vacar599, Ipira599, Palme599 } \\
\text { Sanad599, Pirat599, Saog599 }\end{array}$ \\
\hline A08 & ACGCACAACC & $\begin{array}{l}1.78 \\
1.20 \\
0.88 \\
0.80\end{array}$ & $\begin{array}{l}\text { All isolates } \\
\text { Pirat599 } \\
\text { Ipira599 } \\
\text { All isolates }\end{array}$ \\
\hline B01 & TCGAAGTCCT & $\begin{array}{l}1.93 \\
1.49 \\
1.21 \\
0.81\end{array}$ & $\begin{array}{l}\text { Caraz599, Pirat599, Saog599, Vacar599, Palme599, Encru599, Ipira599 } \\
\text { Caraz599, Sanad599, Saog599, Vacar599, Palme599, Encru599, Ipira599 } \\
\text { Sanad599, Saog599, Vacar599, Palm599, Encru599, Ipira599, Pirat599 } \\
\text { Pirat599 }\end{array}$ \\
\hline B02 & GCATGTCAGA & $\begin{array}{l}1.21 \\
0.96 \\
0.48\end{array}$ & $\begin{array}{l}\text { All isolates } \\
\text { All isolates } \\
\text { Sanad599, Ipira599 }\end{array}$ \\
\hline B06 & GTGACATGCC & $\begin{array}{l}1.05 \\
0.81 \\
0.47\end{array}$ & $\begin{array}{l}\text { All isolates } \\
\text { All isolates } \\
\text { Caraz599, Sanad599, Saog599, Vacar599, Palme599, Encru599, Ipira599 }\end{array}$ \\
\hline
\end{tabular}




\begin{tabular}{|c|c|c|c|}
\hline Primer & Sequence $5^{\prime}-3^{\prime}$ & Fragment size $(\mathrm{kb})$ & D. teres isolate \\
\hline B07 & AGATGCAGCC & $\begin{array}{l}1.59 \\
1.34 \\
0.78 \\
0.51\end{array}$ & $\begin{array}{l}\text { All isolates } \\
\text { All isolates } \\
\text { All isolates } \\
\text { All isolates }\end{array}$ \\
\hline B08 & TCACCACGGT & $\begin{array}{l}1.81 \\
1.38 \\
0.93\end{array}$ & $\begin{array}{l}\text { Caraz599, Sanad599, Saog599, Vacar599, Palme599, Ipira599 } \\
\text { All isolates } \\
\text { All isolates }\end{array}$ \\
\hline B09 & ATGGCTCAG & 1.40 & All isolates \\
\hline B10 & CAGGCACTA & $\begin{array}{l}1.88 \\
1.51 \\
0.77 \\
0.73 \\
0.69 \\
0.64\end{array}$ & $\begin{array}{l}\text { All isolates } \\
\text { Saog599 } \\
\text { Saog599, Vacar599 } \\
\text { Caraz599 } \\
\text { Sanad599, Pirat599, Palme599 Caraz599, Encru599, Ipira599 } \\
\text { Sanad599, Pirat599, Palme599, Encru599, Ipira599 }\end{array}$ \\
\hline OPC02 & GTGAGGCGT & $\begin{array}{l}1.98 \\
1.38\end{array}$ & $\begin{array}{l}\text { All isolates } \\
\text { All isolates }\end{array}$ \\
\hline $\mathrm{OPC} 03$ & GTCGCCGTC & $\begin{array}{l}1.98 \\
1.64 \\
1.52 \\
1.32\end{array}$ & $\begin{array}{l}\text { All isolates } \\
\text { All isolates } \\
\text { All isolates } \\
\text { All isolates }\end{array}$ \\
\hline OPC05 & GATGACCGC & $\begin{array}{l}1.87 \\
1.36 \\
0.91\end{array}$ & $\begin{array}{l}\text { All isolates } \\
\text { Saog599, Vacar599, Caraz599, Encru599, Ipira599 } \\
\text { All isolates }\end{array}$ \\
\hline OPC13 & AAGCCTCGT & $\begin{array}{l}1.67 \\
1.38 \\
1.00 \\
0.64 \\
0.51 \\
0.42\end{array}$ & $\begin{array}{l}\text { All isolates } \\
\text { Caraz599, Sanad599, Saog599, Vacar599, Palme599, Encru599, Ipira599 } \\
\text { All isolates } \\
\text { Palme599 } \\
\text { Pirat599 } \\
\text { Sanad599 }\end{array}$ \\
\hline OPB17 & AGGGAACGA & $\begin{array}{l}1.87 \\
1.52 \\
1.07 \\
0.56 \\
0.47\end{array}$ & $\begin{array}{l}\text { Sanad599 } \\
\text { Sanad599 } \\
\text { Sanad599, Caraz599, Saog599, Vacar599, Palme599 } \\
\text { Encru599, Ipira599 } \\
\text { Sanad599 } \\
\text { All isolates }\end{array}$ \\
\hline
\end{tabular}

pH 8.3; $50 \mathrm{mM} \mathrm{KCl} ; 1.5 \mathrm{mM} \mathrm{MgCl} 2 ; 0.001 \%$ (w/v) gelatin; $2.5 \mathrm{mM}$ of each dNTP; $30 \mathrm{ng}$ of primers; $30 \mathrm{ng}$ genomic DNA and $1 \mathrm{U}$ Taq polymerase. Amplification was carried out in a thermalcycler (Mini Cycler ${ }^{\mathrm{TM}} \mathrm{MJ}$ Research) as follows: one cycle of $1 \mathrm{~min}$ at $94{ }^{\circ} \mathrm{C}, 5 \mathrm{~min}$ at $35^{\circ} \mathrm{C}$ and $2 \mathrm{~min}$ at $72{ }^{\circ} \mathrm{C}$, followed by 45 cycles of $1 \mathrm{~min}$ at $94{ }^{\circ} \mathrm{C}, 1 \mathrm{~min}$ at $35^{\circ} \mathrm{C}$ and $2 \mathrm{~min}$ at $72^{\circ} \mathrm{C}$. Amplification products were separated by electrophoresis in $2 \%(\mathrm{w} / \mathrm{v})$ agarose gel, stained with ethidium bromide and photographed under UV light. All amplifications were repeated at least twice for each isolate in separate experiments.

\section{Data analysis}

Dendrograms were constructed based on morphological analysis and RAPD data using the statistical package of the social sciences (SPSS) software, $2^{\text {nd }}$. Similarity between isolates was assessed by calculating the simple association coefficient and cluster analysis using the un- weighted pair group method with arithmetical averages (UPGMA). The presence or absence (coded as 1 or 0 , respectively) of RAPD bands was used as an additional character for matrix construction.

\section{Results and Discussion}

The Drechslera teres isolates used in this work presented variations in mycelium color, with isolates Pirat599, Encru599, Sanad599 and Saog599 having a Nobles key color of $\mathrm{U}-5-1^{\circ}$ (dark ash) while isolates Palme599, Vacar599 and Caraz599 had a value of U-15-1 ${ }^{\circ}$ (ash) and isolate Ipira599 being white.

Santos (1996), studying Drechslera triti-repentis isolates grown on PDA, and McDonald (1967), working with Pyrenophora teres isolated from different locations, both observed some variability in mycelium color while ValimLabres et al. (1997), Oliveira et al. (1998) and Matsumura (1991) all found variability in mycelium color and colony 
morphology in Bipolaris sorokiniana isolates grown on PDA.

The isolates Sanad599 and Pirat599 exhibited white tufts while isolate Palme599 showed fan shaped sectors, although the surface of all isolates was plain. Santos (1996) also observed white tufts in some $D$. tritici-repentis isolates and Valim-Labres et al. (1997) and Oliveira et al. (1998) found sectors in the form of white and pink tufts in some $B$. sorokiniana isolates.

Of the 27 primers tested, 16 produced reproducible well resolved DNA products, the remaining 11 primers showing either faint or no fragments at all on electrophoresis. Genomic DNA amplification of all isolates produced 62 bands which were submitted to cluster analysis, 56.4\% of the fragments being polymorphic. The sequences of the 16 primers used in this work and their DNA products are shown in Table II. Figures 1 and 2 show the results of RAPD analysis with primers B02, B07 and B10. Four primers B07, B08, OPC03 and OPC02 produced monomorphic fragments with all $D$. teres isolates. Schnell et al. (1995), studying mango isolates (Mangifera indica L.), observed monomorphic amplification with 19 primers. Monomorphic fragments have also been found by Peever and Milgroon (1994) who investigated 16 Pyrenophora teres isolates and by Hamelin et al. (1993) who worked with two Gremmeniella abientina races

The dendrogram constructed with both the RAPD data and morphological characters (Figure 3) presents a major group subdivided into two subgroups, variation in similarity coefficients being between 0.8714 and 0.7286 . Isolates Vacar599 and Saog599, and Encru599 and

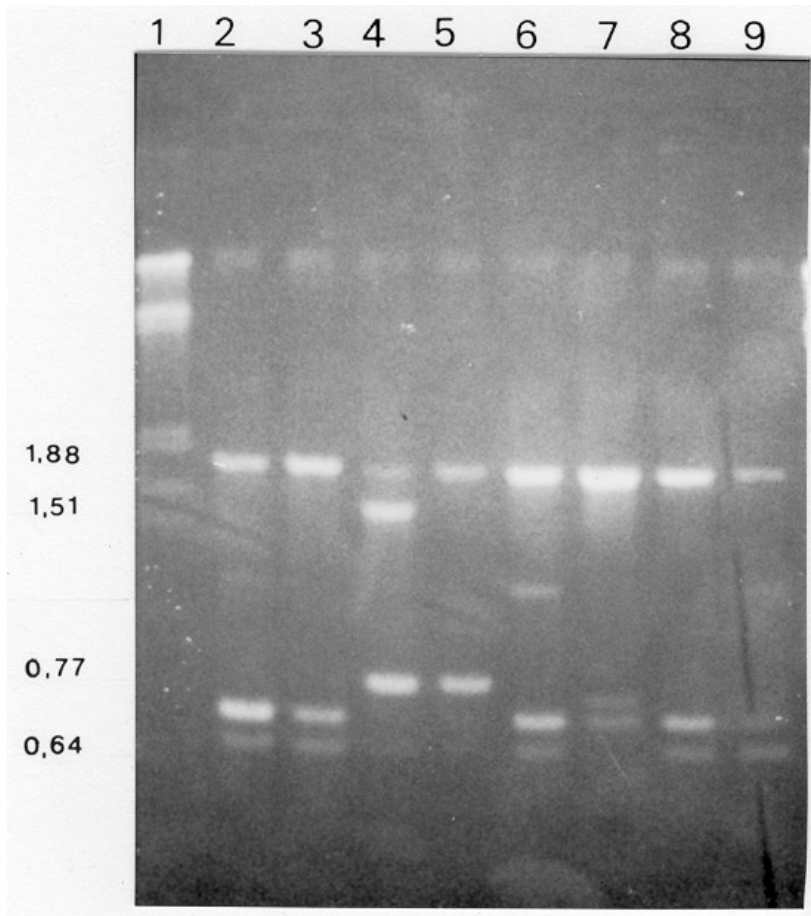

Figure 2 - Amplification products generated from Drechslera teres isolates with primer B10. Lane (1)Lambda DNA digested with EcoRI and HindIII used as molecular weight marker. Lane: (2) isolates Sanad599; (3) Pirat599; (4) Saog599; (5)Vacar599; (6) Palme599; (7) Caraz599; (8) Encru599 (9); Ipira599. Fragment sizes in base pairs are indicated on the right.

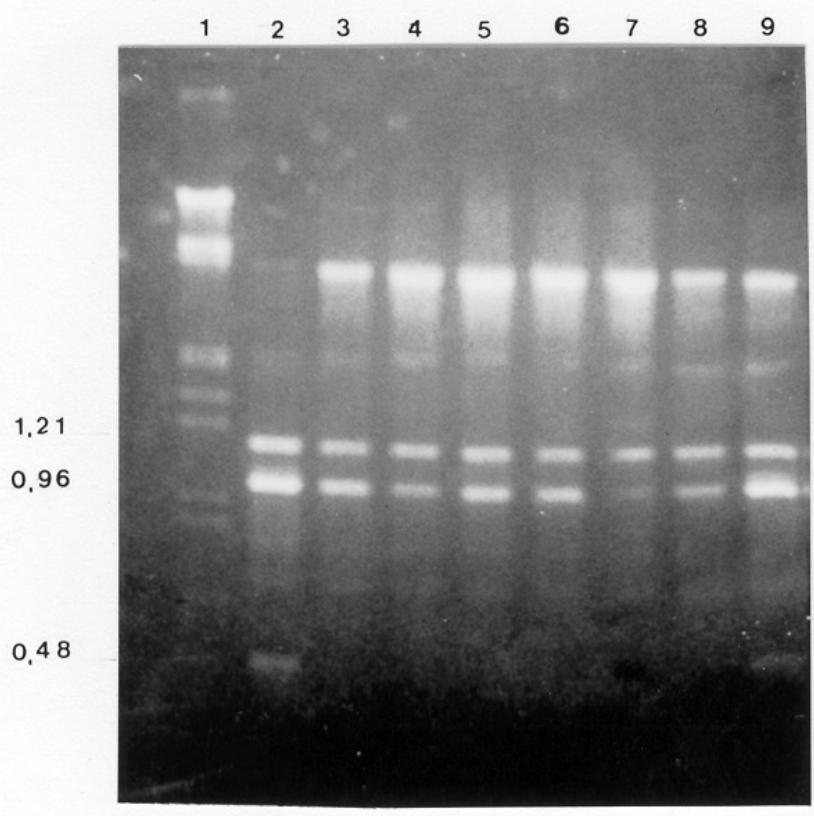

(A)

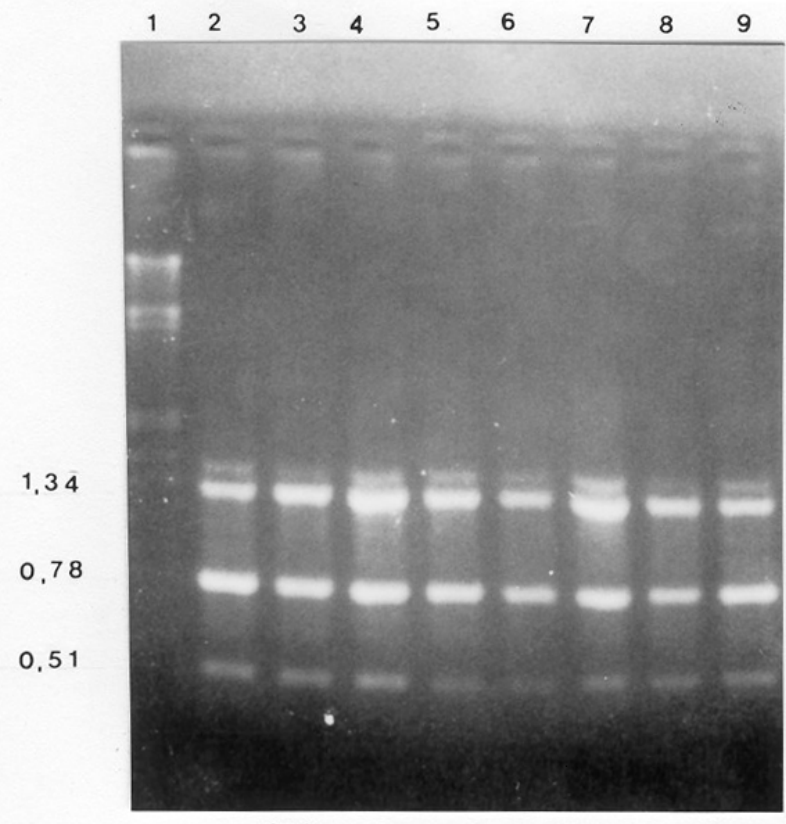

(B)

Figure 1 - Gel showing amplification products from Drechslera teres isolates with primers B02 (A) e B07 (B). Lane (1) Lambda DNA digested with EcoRI and HindIII used as molecular weight marker. Lane: (2) isolates Sanad599; (3) Pirat599; (4) Saog599; (5)Vacar599; (6) Palme599; (7) Caraz599; (8) Encru599; (9) Ipira599. Fragment sizes in base pairs are indicated on the right. 


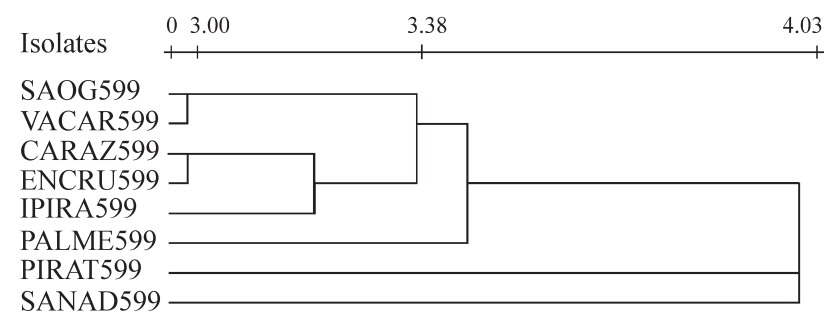

Figure 3 - Dendrogram of the relationships between Drechslera teres isolates based on both colony morphology (edge, texture, color and sector) and random amplified polymorphic DNA (RAPD) analysis.

Caraz599 showed the highest similarity coefficient (0.8714) while the lowest $(0.7286)$ was obtained for isolates Sanad599 and Vacar599. All other isolates presented a similarity coefficient between 0.8571 and 0.7429 (Table III).

In this study a correlation between genetic and morphological variability and the geographic origin of the seeds from which the isolates were obtained could not be established. These findings being similar to those obtained by Valim-Labres (1995) and Oliveira (1995) who worked with B. sorokiniana and Santos (1996) who studied D. tritici-repentis. In our work, this lack of correlation was perhaps due to the lack of multiple samples from the same field or geographic region. Increasing the number of samples and using different primers might result in a correlation. Comparing samples from very different regions of Brazil, or even from different countries, might also allow us to confirm the degree of similarity observed in this work.
Considering only colony morphology the similarity coefficients between isolates were 1.00 to 0.50 (Table IV). The combined culture characteristics of all isolates were analyzed using simple matching coefficients and the dendrogram was constructed (Figure 4). This dendrogram also shows two distinct groups with different similarity levels, one group being formed by isolates Encru599 and Sanad599 (with the highest similarity coefficient of 1.00) and Pirat599 and Vacar599, and a second group which contains all the other isolates.

When only the RAPD data was used cluster analysis showed a main group with decreasing similarity levels, leading to two subgroups. The highest similarity coefficient (0.9032) was observed between isolates Caraz599 and Encru599, and Saog599 and Vacar599. The lowest coefficient in this analysis was 0.7581 , which was seen for isolate Vacar599 in relation to isolates Pirat599 and Sanad599, as well as for isolate Saog599 in relation to isolate Pirat599 (Table V). The similarity coefficient for the 16 primers used in this study was between 75 and $90 \%$. The RAPD results suggest low genetic diversity among the $D$. teres isolates from different geographic regions of Rio Grande do Sul (Figure 5).

Considering all the dendrograms together, it seems that separating morphologic characters and RAPD data did not help in finding a correlation between isolate variability and geographic origin. However Guthrie et al. (1992) and Assigbetse et al. (1994) did succeed in using RAPD analysis to separate isolates based on their geographic origins and DNA amplification products.

Table III - Drechslera teres similarity matrix coefficients based on both colony morphology and random amplified polymorphic DNA (RAPD) analysis.

\begin{tabular}{|c|c|c|c|c|c|c|c|}
\hline Isolates & Caraz599 & Encru599 & Ipira599 & Palme599 & Pirat599 & Sanad599 & Saog599 \\
\hline Encruz599 & 0.8714 & & & & & & \\
\hline Ipira599 & 0.8571 & 0.8429 & & & & & \\
\hline Palme599 & 0.8429 & 0.8000 & 0.8143 & & & & \\
\hline Pirat599 & 0.7571 & 0.8000 & 0.7571 & 0.7714 & & & \\
\hline Sanad599 & 0.7571 & 0.8286 & 0.7571 & 0.7714 & 0.7714 & & \\
\hline Saog599 & 0.8429 & 0.8571 & 0.8143 & 0.8286 & 0.7429 & 0.7714 & \\
\hline Vacr599 & 0.8571 & 0.8143 & 0.8286 & 0.8429 & 0.7571 & 0.7286 & 0.8714 \\
\hline
\end{tabular}

Table IV - Drechslera teres similarity matrix coefficients based on colony morphology only.

\begin{tabular}{|c|c|c|c|c|c|c|c|}
\hline Isolates & Caraz599 & Encru599 & Ipira599 & Palme599 & Sanad599 & Pirat599 & Saog599 \\
\hline Encruz599 & 0.6250 & & & & & & \\
\hline Ipira599 & 0.7500 & 0.6250 & & & & & \\
\hline Palme599 & 0.7500 & 0.6250 & 0.7500 & & & & \\
\hline Sanad599 & 0.6250 & 1.0000 & 0.6250 & 0.6250 & & & \\
\hline Pirat599 & 0.6250 & 0.7500 & 0.6250 & 0.6250 & 0.7500 & & \\
\hline Saog599 & 0.7500 & 0.6250 & 0.7500 & 0.7500 & 0.6250 & 0.6250 & \\
\hline Vacr599 & 0.6250 & 0.5000 & 0.6250 & 0.6250 & 0.5000 & 0.7500 & 0.6250 \\
\hline
\end{tabular}


Table V - Drechslera teres similarity matrix coefficients based on random amplified polymorphic DNA (RAPD) analysis.

\begin{tabular}{|c|c|c|c|c|c|c|c|}
\hline Isolates & Caraz599 & Encru599 & Ipira599 & Palme599 & Pirat599 & Sanad599 & Saog599 \\
\hline Encruz599 & 0.9032 & & & & & & \\
\hline Ipira599 & 0.8710 & 0.8710 & & & & & \\
\hline Palme599 & 0.8387 & 0.8387 & 0.8387 & & & & \\
\hline Pirat599 & 0.7742 & 0.8065 & 0.7742 & 0.8065 & & & \\
\hline Sanad599 & 0.7742 & 0.8065 & 0.7742 & 0.8065 & 0.7742 & & \\
\hline Saog599 & 0.8548 & 0.8871 & 0.8226 & 0.8226 & 0.7581 & 0.7903 & \\
\hline Vacr599 & 0.8871 & 0.8548 & 0.8548 & 0.8548 & 0.7581 & 0.7581 & 0.9032 \\
\hline
\end{tabular}



Figure 4 - Dendrogram of the relationships between Drechslera teres isolates based on colony morphology (edge, texture, color and sector).



Figure 5 - Dendrogram of the relationships between Drechslera teres isolates based on random amplified polymorphic DNA (RAPD) analysis.

Many fungal populations have demonstrated low or moderate levels of genetic variability, and two different hypotheses may account for this. One hypothesis is that proposed by Goodwin et al. (1993), who explain the moderate level of variation seen in Rhychosporium secalis isolates from Europe, Australia and the USA by suggesting that these populations probably originated from the same ancestor. The other hypothesis, suggested by Boerger et al. (1993), proposes that the low genetic differences observed in Mycosphaerella graminicola populations from California and Oregon may be related to gene flow events involving these populations. Both these hypotheses may have a part to play in explaining the low level of genetic difference found among the $D$. teres isolates used in our study.

\section{Acknowledgments}

We thank Maltaria Navegantes for providing the barley seeds. This work was supported by two Brazilian agencies: Conselho Nacional de Desenvolvimento Científico e
Tecnológico $(\mathrm{CNPq})$ and Fundação de Apoio à Pesquisa no Estado do Rio Grande do Sul (FAPERGS).

\section{References}

Alexopoulos CJ and Mims CW (1985) Introdución a la micología. Barcelona Omega Editions, J. Wiley, 683 pp.

Ashktorab H and Cohen RJ (1992) Facile isolation of genomic DNA from filamentous fungi. Bio Techniques 13:198-200.

Assigbetse KB, Fernandez D and Dubois MP (1994) Differentiation of Fusarium oxysporum $\mathrm{f}$. sp. vasinfectum races of cotton by random amplified polymorphic DNA (RAPD) analysis. Phytopatology 84(6):622-626.

Azevedo JL (1976) Variabilidade em fungos fitopatogênicos. Summa Phytopathologica 2:3-15.

Boerger JM, Chen RS and McDonald BA (1993) Gene flow between geographic populations of Mycosphaerella graminicola (anamorph Septoria tritici) detected with restriction fragment lenght polymorphism markers. Phytopathology 83:1148-1154.

Chen X, Line RF and Leung H (1993) Relationship between virulence and DNA polymorphism in Puccinia striiformis. Phytopathology 83(11):1489-1497.

Duncan S, Barton JE and Obrein AP (1993) Analysis of variation in isolates of Rhizoctonia solani by random amplified polymorphic DNA assay. Mycology Research 93(9):1075-1082.

Goodwin SB, Marrof MAS, Allard RW et al. (1993) Isozyme variation within and among populations of Rhynchosporium secalis in Europe, Australia and the United States. Mycology Research 97:49-58.

Guthrie PAI, Magil RA and Frederiksen RA (1992) Random amplified polymorphic DNA markers: a system for identifying and differentiating isolates of Colletotrichum graminicola . Phytopatology 82(8):832-835.

Hamelin RC, Ouellette GB and Bernier I (1993) Identification of Gremmeniella abietina races with random amplified polymorphic DNA markers. Applied. Environmental Microbiology 59:1752-1755.

Jesus J, Cascardo JCM and Figueira A (1995) Uso de marcadores RAPD no estudo de isolados de Fusarium oxysporum f. sp. cubense. Magistra 7:127-149.

Leal JC (1972) Plantas da lavoura sul rio-grandense. Porto Alegre: Faculadade de Agronomia da UFGRS.

Matsumura ATS (1991) Variabilidade intraespecífica quanto a patogenicidade, características de cultura e padrão isoenzimático em populações naturais de Bipolaris sorokiniana (Helminthosporium sativum). Tese Doutorado em Genética, Universidade Federal do Rio Grande do Sul, Porto Alegre. 
Mather ED (1987) Compendium of barley diseases. 3rd ed. The American Phytopathological Society, St. Paul, 78 pp.

McDonald WC (1967) Variability and inheritance of morphological mutants in Pyrenophora teres. Phytopathology 57:747-755.

Nobles M (1958) Cultural characters as a guide to the taxonomy and phylogeny of polyporaceae. Canadian Journal of Botany 36:883-926.

Oliveira AMR (1995) Estudo da variabilidade genética em Bipolaris sorokiniana utilizando técnicas moleculares. Dissertação de Mestrado em Microbiologia Agrícola e do Ambiente, Universidade Federal do Rio Grande do Sul, Porto Alegre.

Oliveira AMR, Prestes, AM, Matos GS, Matsumura AT and Sand ST van der (1998) Variabilidade patogênica e morfológica em isolado de Bipolaris sorokiniana. Fitopatologia Brasileira 23(3):349-353.

Peever TL and Milgroon MG (1994) Genetic structure of Pyrenophora teres populations determined with random amplified polymorphic DNA markers. Canadian Journal of Botany 72:915-923.
Santos AMPV (1996) Análise genotípica de Pyrenophora tritici-repentes (Died.) Drechs. Drechslera tritici-repentis (Died.) Shoem., fitopatógeno do trigo. Dissertação de Mestrado em Microbiologia Agrícola e do Ambiente, Universidade Federal do Rio Grande do Sul, Porto Alegre.

Scnell RJ, Ronning CM and Knight RJ (1995) Identification of cultivars and validation of genetic relationships in Mangifera indica L. using RAPD markers. Theor. Appl. Genet. 90:267-274.

Torno J (1992) As principais doenças fúngicas. Correio Agrícola $1: 12-15$.

Valim-Labres ME (1995) Variabilidade intra-específica em Bipolaris sorokiniana: análise morfológica, isoenzimática e de patogenicidade. Dissertação de Mestrado em Microbiologia Agrícola e do Ambiente, Universidade Federal do Rio Grande do Sul, Porto Alegre.

Valim-labres ME, Prestes AM, Sand ST van der and Matsumura ATS (1997) Variação no aspecto cultural, morfologia e virulência em isolados de Bipolaris sorokiniana de trigo. Fitopatologia Brasileira 22(4):483-487.

Williams JGK, Kubelik AR and Kenneth JL (1990) DNA polymorphisms amplified by arbitrary primers are useful as genetic markers. Nucleic Acids Research 18:6231-635. 